\title{
Thermal treatment of açaí (Euterpe oleracea) fiber for composite reinforcement
}

\author{
Felipe Fernando da Costa Tavares ${ }^{1 *}$ (D), Marcos Danilo Costa de Almeida ${ }^{1}$, João Antonio Pessoa da Silva ${ }^{2}$, \\ Ludmila Leite Araújo무 Nilo Sérgio Medeiros Cardozo² and Ruth Marlene Campomanes Santana ${ }^{1}$ \\ ${ }^{1}$ Laboratório de Materiais Poliméricos - LAPOL, Departamento de Materiais, Escola de Engenharia, \\ Universidade Federal do Rio Grande do Sul - UFRGS, Porto Alegre, RS, Brasil \\ ${ }^{2}$ Laboratório de Processamento e Tecnologia dos Polímeros - LATEP, Departamento de \\ Engenharia Química, Escola de Engenharia, Universidade Federal do Rio Grande do Sul - UFRGS, \\ Porto Alegre, RS, Brasil \\ *felipe.tavares@ueap.edu.br
}

\begin{abstract}
This work investigated the effect of thermal treatment in an autoclave on the chemical, physical, and morphological properties of lignocellulosic fibers from açaí (Euterpe oleracea Mart), and the behavior of this treated fiber in polypropylene (PP) matrix composites with polypropylene-graft-maleic anhydride (PPgMA) as the coupling agent. The treated and untreated fibers were characterized by chemical composition, x-ray diffraction, FTIR spectroscopy, and thermogravimetry, scanning electron microscopy and tensile tests were carried out for the composites. The results showed that the thermal treatment modified the hemicellulose and lignin content and increased the fiber surface roughness, without compromising the thermal stability. The composite prepared with thermally treated fibers and PPgMA exhibited an increase in tensile strength but a reduction in tensile modulus. In conclusion, the thermal treatment of vegetable fiber is a promising technique for improving the performance of composites.
\end{abstract}

Keywords: açai, autoclave, fibers, heat treatment, polypropylene.

How to cite: Tavares, F. F. C., Almeida, M. D. C., Silva, J. A. P., Araújo, L. L., Cardozo, N. S. M., \& Santana, R. M. C. (2020). Thermal treatment of açaí (Euterpe oleracea) fiber for composite reinforcement. Polímeros: Ciência e Tecnologia, 30(1), e2020003. https://doi.org/10.1590/0104-1428.09819

\section{Introduction}

Açaí fibers, Figure 1, have great potential to be used in composites because of their remarkable thermal stability and availability ${ }^{[1]}$. They are found in the external layer of the fruit seed. The seed, which is generally discarded as a residue after separation from the edible pericarp, represents $83 \%$ (wt.) of the fruit ${ }^{[2]}$. However, the fibers can be separated from the internal part of the seed though processing in hammer mills.

Composites with vegetable fibers have attracted attention from the scientific community due to some advantages in relation to conventional fibers, including non-abrasiveness, low density, and relatively low $\cos ^{\left[t^{[3-7]}\right.}$.

Vegetable fibers are natural fibers mainly composed of cellulose, hemicellulose, and lignin. Cellulose constitutes a semi-crystalline structure with thousands of glucose units that confers high mechanical strength to the plant ${ }^{[8-10]}$. Hemicellulose is structurally similar to cellulose, consisting of pentoses and hexoses, and has a great interaction with cellulose ${ }^{[8,9]}$. This compound is responsible for the stability and flexibility of the lignocellulosic system and acts by joining the semi-crystalline bundles of cellulose and maintaining the structure as regularly spaced and organized ${ }^{[9]}$. Lignin is an amorphous polymer with a complex structure based on hydroxyphenylpropane units. This combination of hydroxyl and aromatic groups confers amphipathic properties to lignin and allows its use as a polypropylene fiber coupling agent ${ }^{[10,11]}$. However, Akin ${ }^{[10]}$ reported that lignin has a greater hydrophobic character than cellulose. Lignin is responsible for mechanical rigidity and resistance against microbial pathogens in plant cell walls.

The use of vegetable fibers in combination with thermoplastics polymers for composite preparation presents some drawbacks due to the poor interaction between the fiber/matrix interface, resulting in materials with low-mechanical properties. An approach to improve the performance of this system is using coupling agents ${ }^{[12]}$ or some physicochemical fiber process, such as alkaline and heat treatments.

Coupling agents are macromolecules with polar and non-polar regions and are able to promote physical or chemical linkage between the vegetable fiber and polymer, respectively. Maleic anhydride ${ }^{[13]}$, polyethylene grafted with maleic anhydride (PEgMA $)^{[14]}$, polypropylene grafted with maleic anhydride (PPgMA $)^{[12]}$, diisocyanate ${ }^{[15]}$ and silanes ${ }^{[16]}$ are examples of coupling agents reported in the literature. 

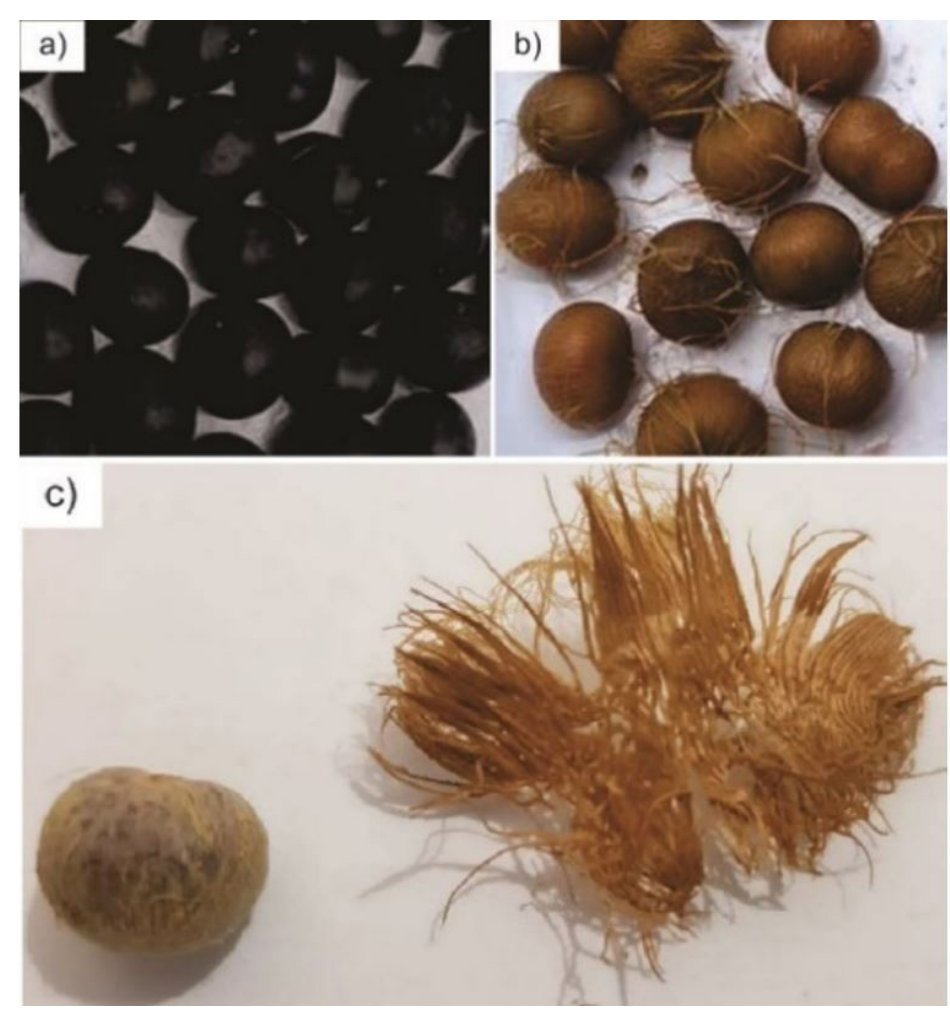

Figure 1. (a) Açaí fruit (average diameter from 1 to $2 \mathrm{~cm}$ and average weight from 0.8 to $2.3 \mathrm{~g}$ ); (b) açaí seeds after removal of the pulp; and (c) internal part of the seed and the fibers obtained after separation in a hammer mill.

Alkaline treatment causes a decrease of the lignin and hemicellulose contents and increases the fiber surface roughness, improving tensile strength and Young's modulus ${ }^{[17-19]}$.

Heat treatment is conducted under air or nitrogen atmosphere or using steam or hot water, representing a chemical-free alternative. It can enhance the dimensional stability, thermal stability, and biological durability of vegetable fibers or wood-based materials ${ }^{[20-22]}$, besides being considered a simple process for obtaining cellulose ${ }^{[23]}$. Hakkou ${ }^{[24]}$, for example, carried out the heat treatment of beech wood under inert atmosphere and reported a significant increase in wood hydrophobicity for treatment temperatures from 130 to $160{ }^{\circ} \mathrm{C}$.

It is reported that the thermal treatment can improve the crystallinity of cellulose and remove impurities of Sinal and Kenal fibes ${ }^{[25,26]}$ and provide better thermal stability for Agave fiber ${ }^{[27]}$. Arwinfar et al ${ }^{[28]}$ noted good compatibility in polypropylene composites with thermally treated beech wood flour and PPgMA, which resulted in higher tensile strength. Unsal and Ayrilmis ${ }^{[29]}$ and Ayrilmis et al. ${ }^{[30]}$ conducted studies on the effects of heat treatment with autoclaved saturated steam at 120,150 and $180^{\circ} \mathrm{C}$. They describe that hemicellulose is generally thermodegraded by hydrolysis, leading to some modifications in wood properties, such as decreased swelling and shrinkage due to reduced water-absorbing capacity, and improved thermal stability. However, other properties are impaired, such as the rupture modulus, elastic modulus, internal bond strength, and compressive strength. In addition to the previously mentioned decrease in compressive strength in heat-treated woods, reductions in wood fiber density and surface hardness were observed by Gunduz et al. ${ }^{[31]}$.

To the extent of our knowledge, the use of açaí fibers submitted to the referred thermal treatment for preparing composites of PP matrix has not yet been carried out. Therefore, based on the promising results obtained, we believe that this investigation is useful to the development of alternative methods for improving the performance of vegetable fibers in composites.

Therefore, in this work, açaí fibers were subjected to an autoclave thermal treatment and used in preparing polypropylene composites containing PPgMA and treated fibers. The effect of the heat treatment on the fiber characteristics and the properties of the obtained composites were evaluated.

\section{Materials and Methods}

\subsection{Materials}

Açaí seeds were collected in Curiaú district (Macapá-Brazil) as a residue of the pulp extraction. At this stage, the fibers and residual pulp are attached to the seed surface. The collected seeds were first cleaned under tap water to remove pulp residues and then dried in an oven at $70{ }^{\circ} \mathrm{C}$ for $24 \mathrm{~h}$. Açaí fibers, which constitute the pericarp of the açaí seeds, were separated from the seeds in a hammer mill (SOLAB apparatus, model SL-034). 
Heterophasic copolymer of polypropylene CP 141 was acquired from BRASKEM (Triunfo, Brazil). Polypropylene grafted with maleic anhydride, PPgAM (PolyBond ${ }^{\circledR} 3200$, Addivant - Molecular weight of $42000 \mathrm{~g} / \mathrm{mol}$ and acid number of $11 \mathrm{mg} \mathrm{KOH} / \mathrm{g}$ ) was provided by Clariant (Novo Hamburgo, Brazil) and used as a compatibilizer agent.

\subsection{Methods}

\subsubsection{Thermal treatment and physico-chemical characterization} of the açaí fibers

The açaí fibers were put into a fabric bag and thermally treated in a PRISMATEC autoclave for $1 \mathrm{~h}$ at $121^{\circ} \mathrm{C}$ and $1 \mathrm{~atm}$. In natura (AF) and treated açaí fibers (TAF) were analyzed for moisture, ash, cellulose, hemicellulose, and lignin contents according to the methodology reported by TAPPI T222 standard ${ }^{[32]}$.

\subsubsection{Production of the açaí fiber composites}

The fibers, both AF and TAF, were previously sieved (mesh sizes: 250 to $1000 \mu \mathrm{m}$ ) and only the fraction of fibers passing the $250 \mu \mathrm{m}$ sieve was employed for composite preparation. PP/fiber (mass proportion of 70:30), and of PP/fiber/PPgMA (mass proportion of 67:30:3) composites were prepared using an internal mixer (Thermo Scientific Haake Rheomix OS) at $180^{\circ} \mathrm{C}, 60 \mathrm{rpm}$ and $5 \mathrm{~min}$ residence time. After mixing, the resulting composite was comminuted in a mill, and subsequently, tensile test specimens were prepared in an injection molding machine (Thermo Scientific Haake, MiniJet II), at $185^{\circ} \mathrm{C}$ and 400 bar, with a $40{ }^{\circ} \mathrm{C}$ mold temperature. The composites produced were designated as $\mathrm{PP} / \mathrm{AF}, \mathrm{PP} / \mathrm{TAF}, \mathrm{PP} / \mathrm{AF} / \mathrm{PPgAM}$ and $\mathrm{PP} / \mathrm{TAF} / \mathrm{PPgAM}$, according to their components.

\subsubsection{Characterization tests}

The mechanical properties were evaluated in a universal testing machine (INSTRON, model 3382). The tensile tests were performed according to ASTM D638, using a type V specimens and $5 \mathrm{~mm} / \mathrm{min}$ crosshead speed.

AF, TAF, PP/AF, PP/TAF, PP/AF/PPgAM, and $\mathrm{PP} / \mathrm{TAF} / \mathrm{PPgAM}$ were characterized by scanning electron microscopy (SEM) in a Hitachi TM3030 Plus Tabletop Microscope, with a $10 \mathrm{kV}$ voltage and 200x magnification. The samples were fixed on stubs with double-sided tape and were not metalized.

$\mathrm{XRD}$ analyses of AF and TAF were performed on a Bruker D2 Phaser, using Ni filter and $\mathrm{Cu}-\alpha$ radiation $(\lambda=1.54 \AA)$ at $30 \mathrm{kV}$, and $2 \Theta$ scan from 5 to $70^{\circ}$. The crystallinity index (CI) was determined according to Segal et al. ${ }^{[33]}$.

FTIR spectra of AF and TAF were obtained in a Perkin Elmer Spectrometer, model Spectrum Two-Ft-IR, with a lithium tantalate detector, using attenuated total reflection analysis (ATR) mode, a wavenumber range of 4000 to $700 \mathrm{~cm}^{-1}$, 16 scans, and $4 \mathrm{~cm}^{-1}$ resolution.
Thermogravimetric analyses of $\mathrm{AF}, \mathrm{TAF}, \mathrm{PP} / \mathrm{AF}$, PP/TAF, PP/AF/PPgAM, and PP/TAF/PPgAM were performed in a NETZSCH TG 209F1 Libra under nitrogen atmosphere flowing at $100 \mathrm{~mL} / \mathrm{min}$, using $10 \mathrm{mg}$ samples, $10^{\circ} \mathrm{C} / \mathrm{min}$ heating rate, and a temperature range from 25 to $800^{\circ} \mathrm{C}$.

\subsubsection{Statistical analysis}

The statistical analysis of the data was performed with Action Stat, using a t-test with a significance level of $95 \%$ $(\mathrm{p}<5 \%)$.

\section{Results and Discussion}

\subsection{Effect of treatment on fiber properties}

Table 1 presents the composition for AF and TAF fibers obtained by chemical analysis. Heat treatment decreased the hemicellulose and lignin contents and increased the moisture and cellulose contents. The most pronounced reduction occurred in the hemicellulose content, which is in agreement with results reported for other vegetal fibers ${ }^{[34]}$. The decrease of the hemicellulose and lignin contents can be attributed to the thermal degradation and lixiviation of these compounds. The thermal degradation of these compounds can be attributed to their structural heterogeneity and lack of crystallinity. In the specific case of lignin, Kim et al. ${ }^{[35]}$ observed that heat treatment promotes rearrangement of the molecular structure and confirmed the cleavage of oxygen bonds in the chain by ${ }^{13} \mathrm{C}$ NMR analysis. The increase of moisture retention for TAF fibers can be explained by the cleavage glycosidic linkages, which expose $\mathrm{OH}$ groups. The apparent increase in cellulose content is probably a direct result of the mass balance due to the reduction of the other components.

The XRD spectra of the AF and TAF fibers are presented in Figure 2. The peaks at $2 \Theta=15^{\circ}$ and $22^{\circ}$ are characteristic of cellulose ${ }^{[36]}$, and it is visible that they presented an increase in the intensity for TAF. The $\mathrm{CI} \%$ calculated for $\mathrm{AF}$ and TAF fibers were $31.3 \%$ and $35.3 \%$, respectively. This result is due to a crystallinity growth of the fiber after the thermal treatment since TAF had a cellulose content higher than $\mathrm{AF}$ fiber, and cellulose is the most crystalline component of the lignocellulosic fiber. Additionally, the extraction of the amorphous components (lignin, hemicellulose, and extractives) by the thermal treatment also contributed to that effect.

The FTIR spectra of the AF and TAF fibers are showed in Figure 3. The bands in the 3200 to $2500 \mathrm{~cm}^{-1}$ range of, related to $\mathrm{OH}$, are assigned to many molecules, such as water, cellulose, hemicellulose, lignin, and extractives ${ }^{[37]}$. At $1722 \mathrm{~cm}^{-1}$, a $\mathrm{C}=\mathrm{O}$ stretching characteristic of carboxyl groups of lignin or groups of hemicelluloses appears ${ }^{[18,38,39]}$, and a reduced intensity of this group is observed for TAF fiber, probably related to the removal of these compounds by the

Table 1. Chemical composition of AF and TAF fibers.

\begin{tabular}{cccccc}
\hline Açaí fiber & Moisture (\%) & Cellulose (\%) & Hemicel. (\%) & Lignin (\%) & Ash (\%) \\
\hline AF & $8.88 \pm 0.16^{\mathrm{a}}$ & $41.37 \pm 1.25^{\mathrm{a}}$ & $11.54 \pm 0.83^{\mathrm{a}}$ & $40.25 \pm 1.35^{\mathrm{a}}$ & $1.96 \pm 0.15^{\mathrm{a}}$ \\
TAF & $9.57 \pm 0.12^{\mathrm{b}}$ & $45.13 \pm 1.94^{\mathrm{b}}$ & $6.60 \pm 1.08^{\mathrm{b}}$ & $32.61 \pm 1.56^{\mathrm{b}}$ & $1.62 \pm 0.18^{\mathrm{a}}$ \\
\hline
\end{tabular}

Different letters in the same column indicate statistically different mean values $(\mathrm{p}<0.05)$. 
autoclaving treatment. Two peaks at 1600 (aromatic skeletal vibration breathing with $\mathrm{C}=\mathrm{O}$ stretching) and $1508 \mathrm{~cm}^{-1}$ (aromatic skeletal vibration) are characteristics of lignin ${ }^{[40,41]}$. The band at $1453 \mathrm{~cm}^{-1}$ is for the $\mathrm{C}-\mathrm{H}$ deformation (methyl and methylene) of lignin ${ }^{[38,40,42,43]}$. The peak at $1272 \mathrm{~cm}^{-1}$

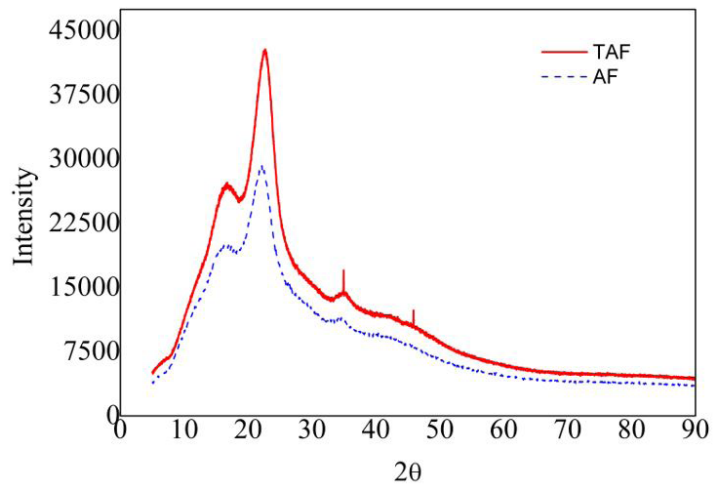

Figure 2. X-ray diffractograms of the AF and TAF fibers.

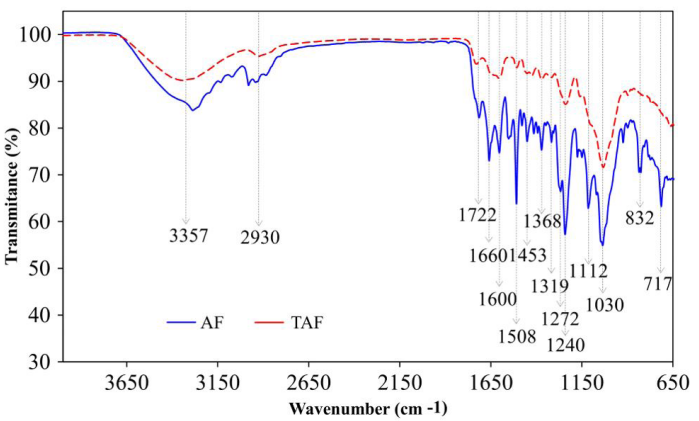

Figure 3. FTIR spectra of AF and TAF fibers.

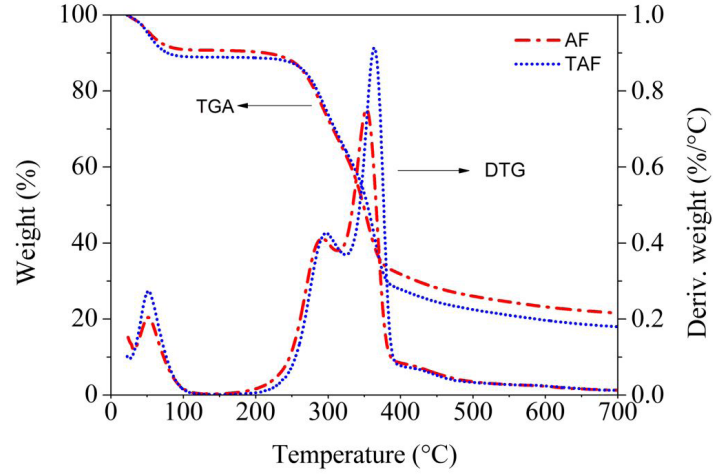

Figure 4. TGA and first derivative of TGA curves for AF and TAF fibers. is related to the $\mathrm{C}-\mathrm{O}$ of the guaiacyl ring of lignin ${ }^{[38,43]}$. The peak at $1240 \mathrm{~cm}^{-1}$ refers to the $\mathrm{C}-\mathrm{O}$ stretching vibration of acetyl groups present in lignin and hemicellulose ${ }^{[38,39]}$. The bands at 1112 and $1030 \mathrm{~cm}^{-1}$ are attributed to $\mathrm{C}-\mathrm{H}$ in-plane deformation of the syringyl unit of lignin and $\mathrm{C}-\mathrm{H}$ deformation in guaiacyl with $\mathrm{C}-\mathrm{O}$ deformation in the primary alcohol, respectively ${ }^{[42]}$. The results can be correlated to the changes in the chemical composition of AF and TAF fibers since a general reduction in the intensity of the groups is observed, mainly those referring to hemicellulose and lignin, and possibly to extractives. Thus, FTIR also confirms the removal of components by the autoclaving treatment.

The thermogravimetric curves (TGA) of the evaluated samples and their respective first derivative (DTGs) are exhibited in Figure 4, while the parameters of the DTG peaks are presented in Table 2. The considered parameters were: $\mathrm{Ti}$, the temperature at $3 \%$ of the total weight loss, used to compare the thermal stability between composites; the maximum temperature (Tmax) and weight loss percentage $\left(\Delta \mathrm{m}_{\mathrm{i}}\right)$ of each peak; and the residue content. The pure fibers (AF and TAF) exhibited an initial weight loss at low temperature $\left(25-100^{\circ} \mathrm{C}\right)$, attributed to the loss of moisture and volatile compounds, such as extractives ${ }^{[37]}$. Due to the character of the initial loss, the thermal stability of the fibers is better represented by the onset temperature of the second thermal event peak, which was designated as Peak 1 because it represents the first thermal degradation process. This temperature was $256{ }^{\circ} \mathrm{C}$ for $\mathrm{AF}$ and $255^{\circ} \mathrm{C}$ for TAF fiber, indicating that the autoclave treatment did not compromise the thermal stability of the fibers.

Three main characteristic events of thermal degradation kinetics were observed on the peak temperatures obtained by DTG. The first one, around $290{ }^{\circ} \mathrm{C}$, is probably related to the thermal degradation of hemicellulose and low-molecular lignin. The second event, near $352^{\circ} \mathrm{C}$, is attributed to cellulose decomposition ${ }^{[44]}$. For AF and TAF fibers, the third event appears as a small shoulder at $400-450{ }^{\circ} \mathrm{C}$ and is due to the decomposition of lignin.

Regarding the residual material at the end of the TGA analysis for the pure fibers, TAF fiber presented a smaller percentage than AF fiber, probably due to the removal of inorganic compounds, including silica and extractives by the thermal treatment. Another possibility is that reported by Dorez et al. ${ }^{[45]}$, who suggest that an interaction between cellulose and lignin during decomposition can affect the ash content due because a decrease in the lignin content leads to decrease in the activation energy of vegetable fiber pyrolysis reactions, thus reducing the amount of residue.

Figure 5 presents surface micrographs of AF and TAF fibers obtained by SEM. AF fiber exhibits an irregular surface on which small spherical particles (highlighted with arrows in

Table 2. Thermal degradation temperatures, DTG peaks and $\%$ residue at $800{ }^{\circ} \mathrm{C}$ for $\mathrm{AF}$ and $\mathrm{TAF}$ fibers.

\begin{tabular}{|c|c|c|c|c|c|c|c|c|}
\hline \multirow[b]{2}{*}{ Sample } & \multirow{2}{*}{$\begin{array}{c}\mathrm{Ti}\left({ }^{\circ} \mathrm{C}\right) \\
3 \mathrm{wt} \% \text { loss }\end{array}$} & \multicolumn{6}{|c|}{ DTG } & \multirow[b]{2}{*}{$\begin{array}{c}\text { Residue } \\
800{ }^{\circ} \mathrm{C}(\%)\end{array}$} \\
\hline & & $\begin{array}{c}\text { Tpeak1 } \\
\left({ }^{\circ} \mathrm{C}\right)\end{array}$ & $\begin{array}{l}\Delta \mathrm{m}_{1} \\
(\%)\end{array}$ & $\begin{array}{c}\text { Tpeak2 } \\
\left({ }^{\circ} \mathrm{C}\right)\end{array}$ & $\begin{array}{l}\Delta \mathrm{m}_{2} \\
(\%)\end{array}$ & $\begin{array}{c}\text { Tpeak3 } \\
\left({ }^{\circ} \mathrm{C}\right)\end{array}$ & $\begin{array}{l}\Delta \mathrm{m}_{3} \\
(\%)\end{array}$ & \\
\hline $\mathrm{AF}$ & 45 & 292 & 23.1 & 353 & 35.3 & $422^{a}$ & 11.8 & 20.4 \\
\hline TAF & 44 & 297 & 24.6 & 364 & 36.3 & $426^{\mathrm{a}}$ & 11.1 & 17.0 \\
\hline
\end{tabular}

${ }^{\mathrm{a}}$ Appears as a shoulder for AF and TAF. 
Figure 5a) are deposited. According to the results presented by Mesquita et al. ${ }^{[46]}$, these particles are composed of silica. Regarding TAF fiber, the following changes are noticed in comparison to the non-treated fibers: partial removal of the silica particles, diameter reduction, and increased surface irregularity. The removal of the silica particles is evidenced by the presence of some globular cavities on the surface of the treated fibers (arrows in Figure 5b).

\subsection{Composites properties}

The thermogravimetric curves (TGA) of the evaluated samples and their respective first derivative (DTGs) are exhibited in Figure 6, the DTG peaks are presented in Table 3. PP/AF composite presented the lowest Ti value, while the others were closer together. However, the increased
Ti for PP/TAF composite may not be related to the treated fiber, since AF and TAF fibers do not exhibit a significant difference, and it is attributed to fluctuations of the thermal analysis. For composites with PPgAM, a better fiber/matrix interaction supposedly led to Ti increased.

The neat PP had higher thermal stability at $3 \%$ of weight loss than composites. For the composites, the observed third event (420 to $480 \mathrm{C}$ ), with the highest area, is mainly related to the decomposition of PP matrix with Tpeak at $454{ }^{\circ} \mathrm{C}$, where is maximum the kinetics of decomposition, although it must also include a small contribution corresponding to the thermal degradation of lignin. Negligible variations for the mass of hemicellulose and lignin were observed (as shown by the values of $\Delta \mathrm{m}_{1}$ and $\Delta \mathrm{m}_{3}$ in Table 3 ) when compared to the chemical analysis results presented in Table 1 . However,
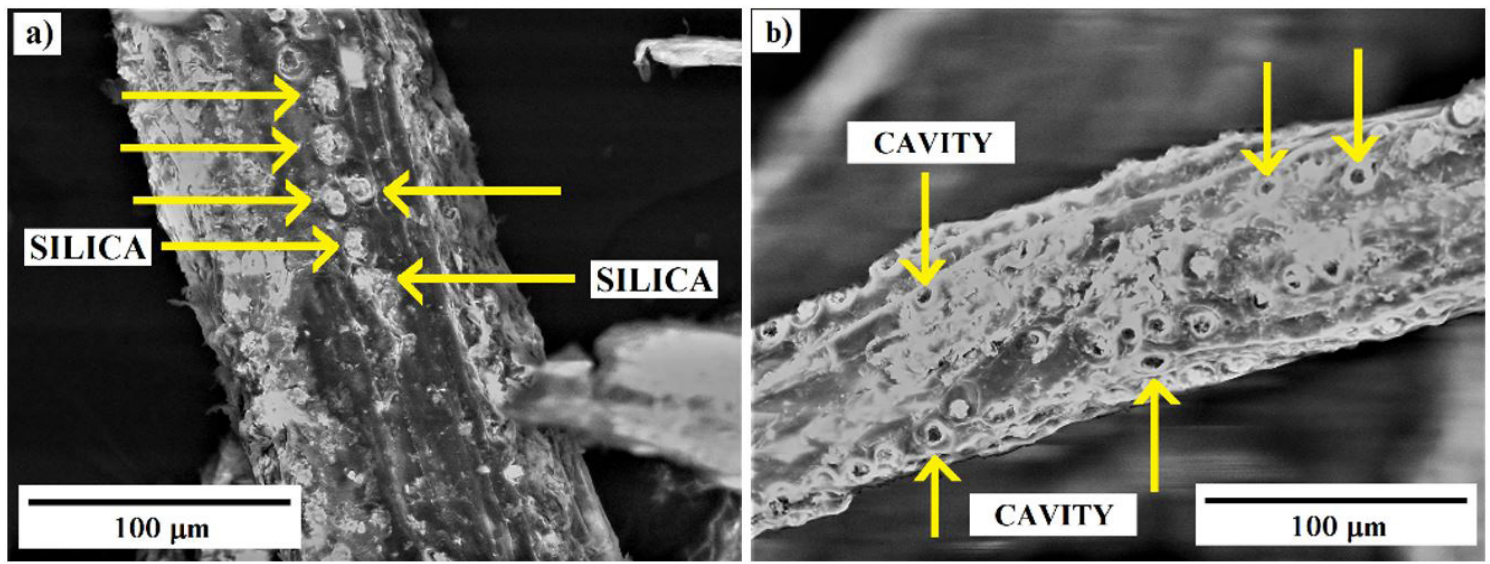

Figure 5. SEM images of the surface of the fibers used: (a) AF; (b) TAF.

a)

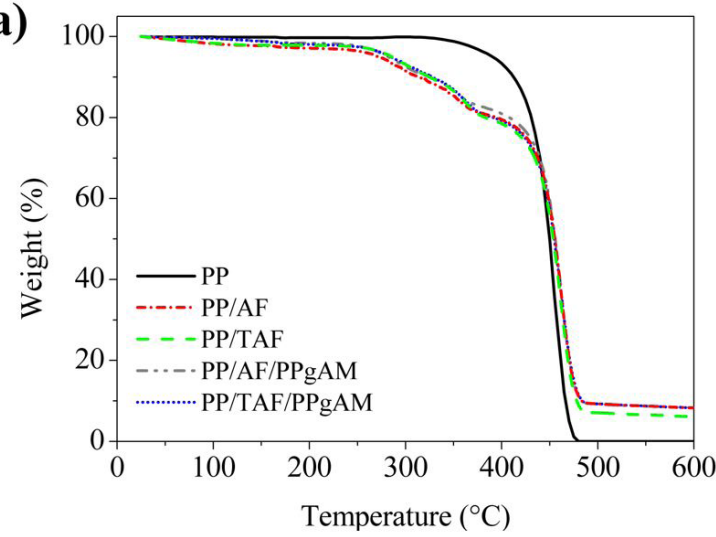

b)

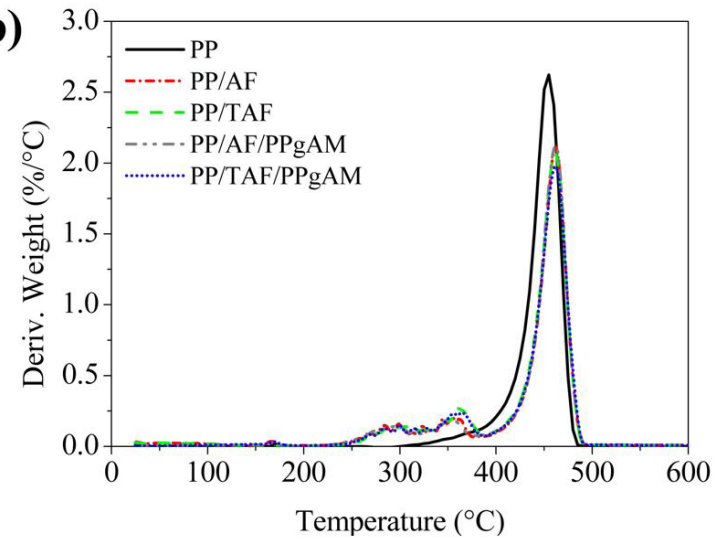

Figure 6. Thermal curves: (a) TGA and (b) The first derivative of TGA for PP/AF, PP/TAF, PP/AF/PPgAM and PP/TAF/PPGAM composites.

Table 3. Thermal degradation temperatures, DTG peaks and $\%$ residue at $800{ }^{\circ} \mathrm{C}$ for composites.

\begin{tabular}{|c|c|c|c|c|c|c|c|c|}
\hline \multirow[b]{2}{*}{ Sample } & \multirow[b]{2}{*}{$\begin{array}{l}\mathrm{Ti}\left({ }^{\circ} \mathrm{C}\right) 3 \\
\text { wt\% loss }\end{array}$} & \multicolumn{6}{|c|}{ DTG } & \multirow[b]{2}{*}{$\begin{array}{c}\text { Residue a } \\
800^{\circ} \mathrm{C}(\%)\end{array}$} \\
\hline & & $\begin{array}{c}\text { Tpeak1 } \\
\left({ }^{\circ} \mathrm{C}\right)\end{array}$ & $\begin{array}{l}\Delta \mathrm{m}_{1} \\
(\%)\end{array}$ & $\begin{array}{c}\text { Tpeak2 } \\
\left({ }^{\circ} \mathrm{C}\right)\end{array}$ & $\begin{array}{l}\Delta \mathrm{m}_{2} \\
(\%)\end{array}$ & $\begin{array}{c}\text { Tpeak3 } \\
\left({ }^{\circ} \mathrm{C}\right)\end{array}$ & $\begin{array}{l}\Delta \mathrm{m}_{3} \\
(\%)\end{array}$ & \\
\hline PP & 375 & - & - & - & - & 454 & 100 & 0 \\
\hline $\mathrm{PP} / \mathrm{AF}$ & 219 & 284 & 9.8 & 355 & 9.4 & 462 & 72.8 & 7.9 \\
\hline $\mathrm{PP} / \mathrm{TAF}$ & 262 & 288 & 10.3 & 361 & 10.2 & 461 & 74.1 & 5.4 \\
\hline PP/AF/PPgMA & 262 & 290 & 7.9 & 352 & 7.9 & 463 & 73.5 & 8.5 \\
\hline PP/TAF/PPgMA & 263 & 303 & 5.3 & 368 & 6.6 & 463 & 79.5 & 8.6 \\
\hline
\end{tabular}


overlapping responses related to the degradation of cellulose, which takes place in an intermediary region $\left(250\right.$ to $\left.380^{\circ} \mathrm{C}\right)$, hemicellulose, and lignin were likely $\mathrm{y}^{[1,17,35,37]}$, which may have masked the results. Analyzing the values of $\mathrm{T}_{\text {peak } 1}$ and $\mathrm{T}_{\text {peak } 2}$ in Table 3, a displacement to higher temperatures is noted when comparing PP/TAF and PP/TAF/PPgAM to $\mathrm{PP} / \mathrm{AF}$ and $\mathrm{PP} / \mathrm{AF} / \mathrm{PPgAM}$, respectively. Similar to the increase of Ti discussed previously, this probably reflects an effective improvement in the fiber/matrix interaction due to the combined action of the treated fibers and the presence of PPgMA. Similar behavior was reported by Redighieri and Costa $^{[47]}$ for composites of recycled polyethylene and wood particles with polyethylene functionalized with maleic anhydride as a compatibilizer agent.

In relation to the composites, the difference of residue content between $\mathrm{PP} / \mathrm{TAF}$ and $\mathrm{PP} / \mathrm{AF}$ is also significant and it can be explained on the same basis as for the fibers. On the other hand, the composites with PPgMA presented higher residue contents compared to the respective composites without the presence of this agent, which may be attributed to the coupling action of PPgMA.

SEM micrographs of the fracture surface of the composites are shown in Figure 7. SEM micrographs of PP/AF and PP/TAF show that thermal treatment alone was not able to improve the fiber/matrix coupling, since both micrographs present similar patterns with voids between the fiber surface and polymeric matrix around it and smooth surface holes due to fiber extraction during the tensile test (indicated by red arrows in Figure 7a and 7b). The reduction of these voids and holes in the micrographs of the composites with a coupling agent (Figure 7c and 7d) indicates that PPgMA developed some level of coupling between the açaí fibers and the PP matrix. Additionally, the more compact structure observed for PP/TAF/PPgMA composite (Figure 7d) suggests that the thermal treatment also contributed to a higher level of fiber/matrix interaction, probably because the surface changes it promotes leads to higher mechanical contact with the coupling agent and the polymeric matrix.
Figure 8 presents the stress vs. strain curves for the evaluated composites; the main results of these curves are summarized in Table 4. In general, when comparing the composites with neat PP, the addition of fibers provided a molecular interlock, increasing modulus and tensile stress, but decreased strain, as reported in the literature ${ }^{[4,7,9,14]}$. The mechanical behaviors of the composites prepared without the addition of PPgMA are quite similar, presenting statistically equal values of modulus and small differences in terms of tensile strength and elongation at rupture. The small values of these last two parameters can be attributed to the defects related to the poor interaction between the fibers and polymeric matrix discussed in the previous section. However, the slight improvement in the tensile stress of $\mathrm{PP} / \mathrm{TAF}$ when compared to PP/AF may be attributed to the higher roughness of the treated fiber. This roughness effect was also observed by Bulut and Aksit ${ }^{[48]}$ for composites of jute fiber and propylene matrix. Regarding the composite $\mathrm{PP} / \mathrm{AF} / \mathrm{PPgMA}$, the change of morphology observed in comparing Figure $7 \mathrm{c}$ with Figure $7 \mathrm{a}, 7 \mathrm{~b}$ is also reflected in the mechanical properties. An increase of tensile strength and a decrease of elongation at break is observed in comparison to $\mathrm{PP} / \mathrm{AF}$ composite, which may be ascribed to a limited action coupling effect exerted by PPgMA with the non-treated açaí fibers due to the lower number of $\mathrm{OH}$ groups in their surface available to react. Finally, PP/TAF/PPgAM composite presented differentiated properties compared to the other three composites, with a reduction of the tensile modulus and simultaneous increase of the tensile strength and elongation at break, indicating a higher coupling action of PPgMA with the presence of treated fibers and, consequently, a higher level of interaction between the fibers and the matrix. This is in agreement with the morphology changes observed in Figure $7 \mathrm{~d}$ and with the results reported by Lopes and Sousa ${ }^{[49]}$ for composites of polypropylene with glass fiber using PPgMA as a compatibilizer. They attributed the effects observed in the mechanical properties to plastic deformation and high shear resistance of the compatibilized interface.

Table 4. Results of the mechanical properties of the PP matrix and composites.

\begin{tabular}{ccccc}
\hline Sample & $\begin{array}{c}\text { Young's modulus } \\
(\mathbf{M P a})\end{array}$ & $\begin{array}{c}\text { Tensile stress at } \\
\text { Maximum / Yield (MPa) }\end{array}$ & $\begin{array}{c}\text { Tensile stress at break } \\
(\text { MPa })\end{array}$ & $\begin{array}{c}\text { Strain at break } \\
(\%)\end{array}$ \\
\hline PP & $71.36 \pm 5^{\mathrm{c}}$ & $19.4 \pm 1.2^{\mathrm{d}}$ & $16.9 \pm 0.8^{\mathrm{c}}$ & $120.8^{\mathrm{a}} \pm 15.8^{\mathrm{a}}$ \\
PP/AF & $1293 \pm 65^{\mathrm{a}}$ & $19.1 \pm 0.2^{\mathrm{d}}$ & $14.2 \pm 1.1^{\mathrm{d}}$ & $6.5^{\mathrm{d}} \pm 0.4^{\mathrm{c}}$ \\
PP/TAF & $1306 \pm 113^{\mathrm{a}}$ & $21.3 \pm 0.4^{\mathrm{c}}$ & $16.6 \pm 0.8^{\mathrm{c}}$ & $5.3 \pm 0.2^{\mathrm{d}}$ \\
PP/AF/PPgMA & $1282 \pm 48^{\mathrm{a}}$ & $25.6 \pm 0.4^{\mathrm{b}}$ & $21.7 \pm 0.7^{\mathrm{b}}$ & $4.6 \pm 0.1^{\mathrm{d}}$ \\
PP/TAF/PPgMA & $887 \pm 16^{\mathrm{b}}$ & $27.5 \pm 1.0^{\mathrm{a}}$ & $25.9 \pm 0.6^{\mathrm{a}}$ & $9.3 \pm 1.2^{\mathrm{b}}$ \\
\hline
\end{tabular}

Different letters in the same column represent statistically different means $(\mathrm{p}<0.05)$.

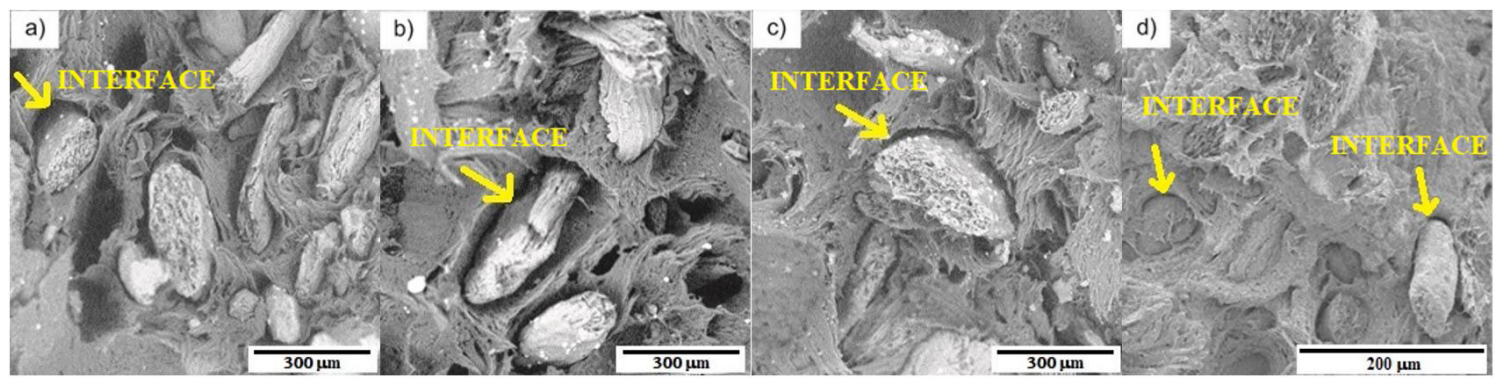

Figure 7. SEM of the fracture impact surface of the composites: (a) PP/AF; (b) PP/TAF; (c) PP/AF/PPgMA; and (d) PP/TAF/PPgMA. 


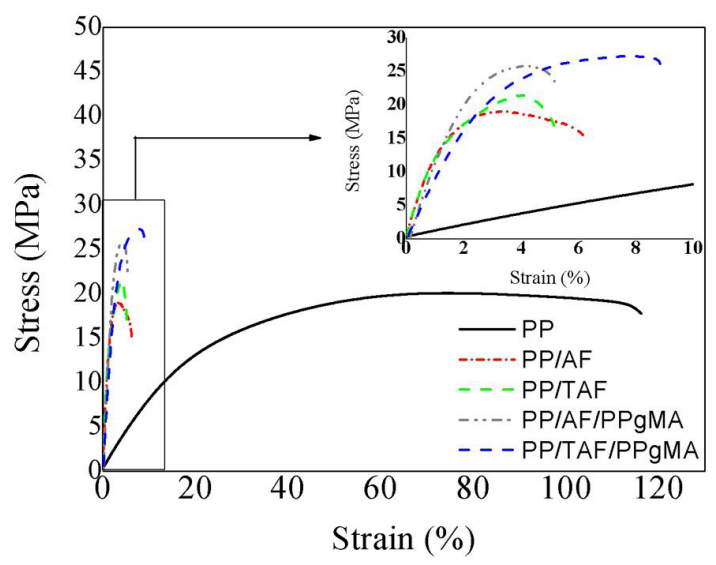

Figure 8. Stress vs. strain curves for the PP matrix and composites.

\section{Conclusions}

Açaí fibers were submitted to thermal treatment in an autoclave at $121{ }^{\circ} \mathrm{C}$ and $1 \mathrm{~atm}$ and polypropylene composites were prepared using treated and non-treated fibers. The thermal treatment of the açaí fibers promoted a reduction in the hemicellulose and lignin content, which contributed to an increase of the fiber crystallinity, partial removal of surface silica particles, and an increase in the fiber surface roughness, without compromising the thermal stability of the fibers.

The morphology and mechanical properties of the $\mathrm{PP} /$ fiber composites produced with the treated and non-treated fibers were quite similar. In the case of the PP/PPgMA/fiber composites, the use of the treated fibers has effectively improved the interaction between the fibers and the $\mathrm{PP} /$ matrix, reducing the occurrence of the volumetric defects (voids between the fibers and the matrix). The use of thermally treated fibers together with PPgMA led to a composite with significantly improved tensile strength but with a reduction in the tensile modulus.

The effectiveness of the proposed water vapor based thermal treatment in improving the coupling action in the ternary composite and the good mechanical properties of this composite indicates the potential of this process as an environment-friendly alternative for the destination of the fibers generated as by-products in açaí fruit processing.

\section{Acknowledgements}

We would like to thank the technicians at the Laboratory of Polymer Materials (LAPOL) of the Federal University of Rio Grande do Sul (UFRGS), in the State University of Amapá (UEAP), and Rede de Saneamento e Abastecimento de Água - Sistema Brasileiro de Tecnologia (RESAG-SIBRATEC).

\section{References}

1. Martins, M. A., Pessoa, J. D. C., Gonçalves, P. S., Souza, F. I., \& Mattoso, L. H. C. (2008). Thermal and mechanical properties of the açaí fiber/natural rubber composites. Journal of Materials Science, 43(19), 6531-6538. http://dx.doi.org/10.1007/s10853008-2842-4.
2. Rogez, H. (2000) Açaí: preparo, composição e melhoramento da conservação. Belém: EDUFPA.

3. Nabi Saheb, D., \& Jog, J. P. (1999). Natural fiber polymer composites: a review. Advances in Polymer Technology, 18(4), 351-363. http://dx.doi.org/10.1002/(SICI)10982329(199924)18:4<351::AID-ADV6>3.0.CO;2-X.

4. Bourmaud, A., \& Baley, C. (2009). Rigidity analysis of polypropylene/vegetal fibre composites after recycling. Polymer Degradation \& Stability, 94(3), 297-305. http://dx.doi. org/10.1016/j.polymdegradstab.2008.12.010.

5. De la Orden, M. U., González Sánchez, C., González Quesada, M., \& Martínez Urreaga, J. (2010). Effect of different coupling agents on the browning of cellulose-polypropylene composites during melt processing. Polymer Degradation \& Stability, 95(2), 201-206. http://dx.doi.org/10.1016/j. polymdegradstab.2009.11.024.

6. Miraoui, I., \& Hassis, H. (2012). Mechanical model for vegetal fibers-reinforced composite materials. Physics Procedia, 25, 130-136. http://dx.doi.org/10.1016/j.phpro.2012.03.061.

7. Granda, L. A., Espinach, F. X., Lopez, F., García, J. C., Delgado-Aguilar, M., \& Mutje, P. (2016). Semichemical fibres of Leucaena collinsii reinforced polypropylene: macromechanical and micromechanical analysis. Composites. Part B, Engineering, 91, 384-391. http://dx.doi.org/10.1016/j. compositesb.2016.01.035.

8. Santos, F. A., Queiroz, J. H., Colodette, J. L., Fernandes, A. S., Guimarães, V. M., \& Rezende, S. T. (2012). Potencial da palha de cana-de-açúcar para produção de etanol. Quimica Nova, 35(5), 1004-1010. http://dx.doi.org/10.1590/S010040422012000500025.

9. Fornari, C. C. M., Jr. (2017). Fibras vegetais para compósitos poliméricos. Ilheus: EDITUS.

10. Akin, D. E. (2010). Chemistry of plant fibres. In J. Müssig (Ed.), Industrial applications of natural fibres: structure, properties and technical applications (pp. 13-22). Georgia: Wiley.

11. Rozman, H. D., Tan, K. W., Kumar, R. N., Abubakar, A., Mohd. Ishak, Z. A., \& Ismail, H. (2000). The effect of lignin as a compatibilizer on the physical properties of coconut fiberpolypropylene composites. European Polymer Journal, 36(7), 1483-1494. http://dx.doi.org/10.1016/S0014-3057(99)00200-1.

12. Catto, A. L., Stefani, B. V., Ribeiro, V. F., \& Santana, R. M. C. (2014). Influence of coupling agent in compatibility of postconsumer HDPE in thermoplastic composites reinforced with eucalyptus fiber. Materials Research, 17(Suppl. 1), 203-209. http://dx.doi.org/10.1590/S1516-14392014005000036.

13. Yu, T., Jiang, N., \& Li, Y. (2014). Study on short ramie fiber/ poly(lactic acid) composites compatibilized by maleic anhydride. Composites. Part A, Applied Science and Manufacturing, 64, 139-146. http://dx.doi.org/10.1016/j.compositesa.2014.05.008.

14. Grison, K., Turella, T. C., Scienza, L. C., \& Zattera, A. J. (2015). Evaluation of the mechanical and morphological properties of HDPE composites with powdered Pinus taeda and calcined alumina. Polímeros: Ciência e Tecnologia, 25(4), 408-413. http://dx.doi.org/10.1590/0104-1428.1852.

15. Yu, T., Hu, C., Chen, X., \& Li, Y. (2015). Effect of diisocyanates as compatibilizer on the properties of ramie/poly(lactic acid) (PLA) composites. Composites. Part A, Applied Science and Manufacturing, 76, 20-27. http://dx.doi.org/10.1016/j. compositesa.2015.05.010.

16. Zhou, F., Cheng, G., \& Jiang, B. (2014). Effect of silane treatment on microstructure of sisal fibers. Applied Surface Science, 292, 806-812. http://dx.doi.org/10.1016/j.apsusc.2013.12.054.

17. Khan, J. A., Khan, M. A., \& Islam, R. (2012). Effect of mercerization on mechanical, thermal and degradation characteristics of jute fabric-reinforced polypropylene 
composites. Fibers and Polymers, 13(10), 1300-1309. http:// dx.doi.org/10.1007/s12221-012-1300-8.

18. Kim, J. T., \& Netravali, A. N. (2010). Mercerization of sisal fibers: effect of tension on mechanical properties of sisal fiber and fiber-reinforced composites. Composites. Part A, Applied Science and Manufacturing, 41(9), 1245-1252. http://dx.doi. org/10.1016/j.compositesa.2010.05.007.

19. Razera, I. A. T., Silva, C. G., Almeida, E. V. R., \& Frollini, E. (2015). Treatments of jute fibers aiming at improvement of fiber-phenolic matrix adhesion. Polímeros: Ciência e Tecnologia, 24(4), 417-421. http://dx.doi.org/10.1590/0104-1428.1738.

20. Mohebby, B., Ilbeighi, F., \& Kazemi-Najafi, S. (2008). Influence of hydrothermal modification of fibers on some physical and mechanical properties of medium density fiberboard (MDF). Holz als Roh- und Werkstoff, 66(3), 213-218. http://dx.doi. org/10.1007/s00107-008-0231-y.

21. Pelaez-Samaniego, M. R., Yadama, V., Lowell, E., \& EspinozaHerrera, R. (2013). A review of wood thermal pretreatments to improve wood composite properties. Wood Science and Technology, 47(6), 1285-1319. http://dx.doi.org/10.1007/ s00226-013-0574-3.

22. Tuong, V. M., \& Li, J. (2011). Changes caused by heat treatment in chemical composition and some physical properties of acacia hybrid sapwood. Holzforschung, 65(1), 67-72. http://dx.doi. org/10.1515/hf.2010.118.

23. Lavoie, J.-M., \& Beauchet, R. (2012). Biorefinery of Cannabis sativa using one- and two-step steam treatments for the production of high quality fibres. Industrial Crops and Products, 37(1), 275-283. http://dx.doi.org/10.1016/j.indcrop.2011.11.016.

24. Hakkou, M., Pétrissans, M., Zoulalian, A., \& Gérardin, P. (2005). Investigation of wood wettability changes during heat treatment on the basis of chemical analysis. Polymer Degradation \& Stability, 89(1), 1-5. http://dx.doi.org/10.1016/j. polymdegradstab.2004.10.017.

25. Balla, V. K., Kate, K. H., Satyavolu, J., Singh, P., \& Tadimeti, J. G. D. T. (2019). Additive manufacturing of natural fiber reinforced polymer composites: processing and prospects. Composites. Part B, Engineering, 174, 106956. http://dx.doi. org/10.1016/j.compositesb.2019.106956.

26. Carada, T. D. L., Fujii, T., \& Okubo, K. (2016). Effects of heat treatment on the mechanical properties of kenaf fiber. AIP Conference Proceedings, 1736, 020029. http://dx.doi. org/10.1063/1.4949604.

27. Langhorst, A., Paxton, W., Bollin, S., Frantz, D., Burkholder, J., Kiziltas, A., \& Mielewski, D. (2019). Heat-treated blue agave fiber composites. Composites. Part B, Engineering, 165, 712724. http://dx.doi.org/10.1016/j.compositesb.2019.02.035.

28. Arwinfar, F., Hosseinihashemi, S. K., Latibari, A. J., Lashgari, A., \& Ayrilmis, N. (2016). Mechanical properties and morphology of wood plastic composites produced with thermally treated beech wood. BioResources, 11, 1494-1504. http://dx.doi. org/10.15376/biores.11.1.1494-1504.

29. Unsal, O., \& Ayrilmis, N. (2005). Variation in compression strength and surface roughness of heat-treated Turkish river red gum (Eucalyptus camaldulensis) wood. Journal of Wood Science, 51(4), 405-409. http://dx.doi.org/10.1007/s10086004-0655-x

30. Ayrilmis, N., Jarusombuti, S., Fueangviat, V., \& Bauchongkol, P. (2011). Effects of thermal treatment of rubberwood fibres on physical and mechanical properties of medium density fibreboard. Journal of Tropical Forest Science, 23(1), 10-11. Retrieved in 2019, December 4, from https://www.jstor.org/ stable/2361687

31. Gunduz, G., Aydemir, D., \& Karakas, G. (2009). The effects of thermal treatment on the mechanical properties of wild pear (Pyrus elaeagnifolia Pall) wood and changes in physical properties. Materials \& Design, 30(10), 4391-4395. http:// dx.doi.org/10.1016/j.matdes.2009.04.005.

32. Technical Association of the Pulp \& Paper Industry. (2002). TAPPI T 222: acid-insoluble lignin in wood and pulp. Atlanta: TAPPI.

33. Segal, L., Creely, J. J., Martin, A. E., Jr., \& Conrad, C. M. (1959). An empirical method for estimating the degree of crystallinity of native cellulose using the $\mathrm{X}$-ray diffractometer. Textile Research Journal, Princeton, 29(10), 786-794. http:// dx.doi.org/10.1177/004051755902901003.

34. Yildiz, S., Gezer, E. D., \& Yildiz, U. C. (2006). Mechanical and chemical behavior of spruce wood modified by heat. Building and Environment, 41(12), 1762-1766. http://dx.doi. org/10.1016/j.buildenv.2005.07.017.

35. Kim, J. Y., Hwang, H., Oh, S., Kim, Y. S., Kim, U. J., \& Choi, J. W. (2014). Investigation of structural modification and thermal characteristics of lignin after heat treatment. International Journal of Biological Macromolecules, 66, 57-65. http://dx.doi. org/10.1016/j.ijbiomac.2014.02.013. PMid:24530642.

36. Rambo, M. K. D., Schmidt, F. L., \& Ferreira, M. M. C. (2015). Analysis of the lignocellulosic components of biomass residues for biorefinery opportunities. Talanta, 144, 696-703. http:// dx.doi.org/10.1016/j.talanta.2015.06.045. PMid:26452879.

37. Moura, A., Bolba, C., Demori, R., Lima, L. P. F. C., \& Santana, R. M. C. (2017). Effect of rice husk treatment with hot water on mechanical performance in poly(hydroxybutyrate)/rice husk biocomposite. Journal of Polymers and the Environment, 26(6), 2632-2639. http://dx.doi.org/10.1007/s10924-017-1156-5.

38. Huang, L., Mu, B., Yi, X., Li, S., \& Wang, Q. (2016). Sustainable use of coffee husks for reinforcing polyethylene composites. Journal of Polymers and the Environment, 26(1), 48-58. http:// dx.doi.org/10.1007/s10924-016-0917-x.

39. Masłowski, M., Miedzianowska, J., \& Strzelec, K. (2018). Natural rubber composites filled with cereals straw modified with acetic and maleic anhydride: preparation and properties. Journal of Polymers and the Environment, 26(10), 4141-4157. http://dx.doi.org/10.1007/s10924-018-1285-5.

40. Rashid, T., Kait, C. F., \& Murugesan, T. (2016). A "Fourier Transformed infrared" compound study of lignin recovered from a formic acid process. Procedia Engineering, 148, 13121319. http://dx.doi.org/10.1016/j.proeng.2016.06.547.

41. Kaparaju, P., \& Felby, C. (2010). Characterization of lignin during oxidative and hydrothermal pre-treatment processes of wheat straw and corn stover. Bioresource Technology, 101(9), 3175-3181. http://dx.doi.org/10.1016/j.biortech.2009.12.008. PMid:20056415.

42. Kubo, S., \& Kadla, J. F. (2005). Hydrogen bonding in lignin: a Fourier transform infrared model compound study. Biomacromolecules, 6(5), 2815-2821. http://dx.doi.org/10.1021/ bm050288q. PMid:16153123.

43. Poletto, M., \& Zattera, A. J. (2013). Materials produced from plant biomass: part III: degradation kinetics and hydrogen bonding in lignin. Materials Research, 16(5), 1065-1070. http://dx.doi.org/10.1590/S1516-14392013005000112.

44. Poletto, M., Zeni, M., \& Zattera, A. J. (2012). Effects of wood flour addition and coupling agent content on mechanical properties of recycled polystyrene/wood flour composites. Journal of Thermoplastic Composite Materials, 25(7), 821833. http://dx.doi.org/10.1177/0892705711413627.

45. Dorez, G., Ferry, L., Sonnier, R., Taguet, A., \& Lopez-Cuesta, J. M. (2014). Effect of cellulose, hemicellulose and lignin contents on pyrolysis and combustion of natural fibers. Journal of Analytical and Applied Pyrolysis, 107, 323-331. http://dx.doi. org/10.1016/j.jaap.2014.03.017.

46. Mesquita, A. L., Barrero, N. G., Fiorelli, J., Christoforo, A. L., De Faria, L. J. G., \& Lahr, F. A. R. (2018). Eco-particleboard 
manufactured from chemically treated fibrous vascular tissue of acai (Euterpe oleracea Mart.) Fruit: A new alternative for the particleboard industry with its potential application in civil construction and furniture. Industrial Crops and Products, 112, 644-651. http://dx.doi.org/10.1016/j.indcrop.2017.12.074.

47. Redighieri, K. I., \& Costa, D. A. (2008). Composites of recycled polyethylene and reforestation wood particles treated with modified polyethylene. Polimeros: Ciência e Tecnologia, 18(1), 5-11. http://dx.doi.org/10.1590/S0104-14282008000100006.

48. Bulut, Y., \& Aksit, A. (2013). A comparative study on chemical treatment of jute fiber: potassium dichromate, potassium permanganate, and sodium perborate trihydrate. Cellulose, 20(6), 3155-3164. http://dx.doi.org/10.1007/s10570-013-0049-6.

49. Lopes, P. E., \& Sousa, J. A. (1999). Influence of interface/ interphase characteristics on mechanical properties of polypropylene/glass fiber composites with PP-g-MAH intefacial compatibilizer. Polímeros: Ciência e Tecnologia, 9(4), 98-103. http://dx.doi.org/10.1590/S0104-14281999000400017.

Received: Dec. 04, 2019

Revised: Mar. 22, 2020

Accepted: Apr. 06, 2020 